Thorax, 1979, 34, 29-32

\title{
Intrathoracic manifestations in non-Hodgkin's
} lymphoma

\author{
A MANOHARAN, ${ }^{1}$ W R PITNEY, ${ }^{1}$ M E SCHONELL, ${ }^{2}$ AND L V BADER ${ }^{3}$ \\ From the Departments of Clinical Haematology, ${ }^{1}$ Respiratory Medicine, ${ }^{2}$ and Histopathology, ${ }^{3}$ \\ The St George Hospital, University of New South Wales, Sydney, Australia
}

ABSTRACT A total of 16 of 86 patients (19\%) with non-Hodgkin's lymphoma were found to have intrathoracic disease in this retrospective study. Paratracheal, mediastinal, and hilar lymphadenopathy was the commonest manifestation followed by pulmonary lesions and pleural effusion. The lymphoma was at an advanced clinical stage in all the patients with intrathoracic disease. About one-third of the intrathoracic lesions first developed at the time of relapse after successful initial therapy. There was a better response to therapy when intrathoracic disease was part of the initial presentation than when it was a manifestation of relapse. If it did not respond to therapy it was always indicative of a poor prognosis.

Intrathoracic radiographic abnormalities in patients with malignant lymphoma may be due to the disease itself; complications related to the disease and therapy, for instance, infection, fibrosis, or haemorrhage; or unrelated disorders, such as pulmonary infarction. Intrathoracic disease is common in Hodgkin's lymphoma, occurring in $50-60 \%$ of patients (Moran and Ultmann, 1974; Macdonald, 1977). The overall prevalence of intrathoracic disease in patients with non-Hodgkin's lymphoma (NHL) is not known, although the frequency of mediastinal and hilar lymphadenopathy and pleural effusion in untreated patients has been reported (Rosenberg et al, 1961; Jones et al, 1973). In the present retrospective study the intrathoracic manifestations of all patients with NHL attending the St George Hospital over an eight-year period are reported.

\section{Patients and methods}

The chest radiographs of all patients with NHL attending the clinical haematology unit from 1970 to 1977 were examined for intrathoracic lesions. Patients were excluded from the study if the radiographic abnormalities were accompanied by clinical or laboratory evidence indicating a non-lymphomatous nature, or if the abnormalities were related to chest diseases present before the onset of lymphoma-for example, chronic bronchitis or pulmonary tuberculosis. Radiographic abnormalities were subdivided into paratracheal, mediastinal, and hilar lymphadenopathy, pulmonary lesions, and pleural effusion. The histological material was reviewed and classified on morphological criteria according to the recommendations of Braylan et al (1975). The clinical stage (Carbone et al, 1971) and histological type of lymphoma, the treatment, and the subsequent course of the disease were related to the radiographic abnormalities. It was also recorded whether the radiographic abnormality was first detected at the time of the initial diagnosis of NHL or at relapse. Relapse was defined as reappearance of tumour masses or systemic symptoms.

\section{Results}

Table 1 shows the prevalence of intrathoracic disease in patients with the various subtypes of NHL and the clinical details of the patients with radiographic abnormalities due to intrathoracic lymphoma. Eighty-six patients were studied, and $16(19 \%)$ had radiographic abnormalities. There were no radiographic abnormalities in patients with diffuse pattern lymphoma of poorly differentiated lymphocytic type or mixed histiocyticlymphocytic type. The single patient with Lennert's lymphoma and undifferentiated type of lymphoma also had no abnormalities.

A total of 24 radiographic abnormalities were noted in the 16 patients and seven of the patients had two or more types of lesion. Paratracheal, mediastinal, and hilar lymphadenopathy accounted 
Table 1 Intrathoracic disease in non-Hodgkin's lymphoma

\begin{tabular}{|c|c|c|c|c|c|c|c|c|c|c|}
\hline \multirow{3}{*}{$\begin{array}{l}\text { Histological } \\
\text { type* }\end{array}$} & \multirow{3}{*}{$\begin{array}{l}\text { Total no } \\
\text { of patients }\end{array}$} & \multirow{3}{*}{$\begin{array}{l}\text { No of } \\
\text { patients } \\
\text { with } \\
\text { radiographic } \\
\text { abnormali- } \\
\text { ties }\end{array}$} & \multicolumn{8}{|c|}{ Clinical details of patients with radiographic abnormalities } \\
\hline & & & \multirow[t]{2}{*}{ Patient } & \multirow[t]{2}{*}{$\operatorname{Sex}$} & \multirow{2}{*}{ Age } & \multirow{2}{*}{$\begin{array}{l}\text { Clinical } \\
\text { stage of } \\
\text { NHL }\end{array}$} & \multicolumn{2}{|c|}{ Radiographic abnormality } & \multirow{2}{*}{$\begin{array}{l}\text { Response to } \\
\text { therapy }\end{array}$} & \multirow{2}{*}{$\begin{array}{l}\text { Follow-up } \\
\text { (months) }\end{array}$} \\
\hline & & & & & & & Type & First noted at & & \\
\hline \multirow[t]{2}{*}{ PDLN } & 13 & 3 & 1 & $\mathbf{M}$ & 39 & IV & $\begin{array}{l}\text { Pulmonary } \\
\text { pleural eff } \dagger\end{array}$ & Diagnosis & Complete & 8 \\
\hline & & & $\begin{array}{l}2 \\
3\end{array}$ & $\begin{array}{l}\mathbf{M} \\
\mathbf{M}\end{array}$ & $\begin{array}{l}64 \\
49\end{array}$ & $\begin{array}{l}\text { IV } \\
\text { III }\end{array}$ & $\begin{array}{l}\text { Paratracheal } \\
\text { Paratracheal } \\
\text { mediastinal } \\
\text { and hilar }\end{array}$ & $\begin{array}{l}\text { Diagnosis } \\
\text { Diagnosis }\end{array}$ & $\begin{array}{l}\text { Partial } \\
\text { Complete }\end{array}$ & $\begin{array}{l}27 \\
18 \S\end{array}$ \\
\hline \multirow[t]{3}{*}{ HLN } & 12 & 3 & 4 & $\mathbf{F}$ & 76 & IV & $\begin{array}{l}\text { Mediastinal } \\
\text { and hilar }\end{array}$ & Diagnosis & Partial & \\
\hline & & & 5 & $\mathbf{F}$ & 64 & III & $\begin{array}{l}\text { Pleural eff } \dagger \\
\text { Paratracheal } \\
\text { mediastinal } \\
\text { and hilar }\end{array}$ & $\begin{array}{l}\text { Relapse } \\
\text { Diagnosis }\end{array}$ & $\begin{array}{l}\text { Complete } \\
\text { Complete }\end{array}$ & $\begin{array}{l}33 \\
10\end{array}$ \\
\hline & & & 6 & $\mathbf{F}$ & 60 & III & $\begin{array}{l}\text { Mediastinal } \\
\text { and hilar } \\
\text { pulmonarył }\end{array}$ & Relapse & No & $12 \S$ \\
\hline \multirow[t]{2}{*}{ WDLD } & 9 & 2 & 7 & $\mathbf{M}$ & 39 & IV & \multirow{2}{*}{$\begin{array}{l}\text { Mediastinal } \\
\text { and hilar } \\
\text { Pulmonary }\end{array}$} & Relapse & No & 64 \\
\hline & & & 8 & $\mathbf{F}$ & 71 & IV & & Relapse & Partial & 33 \\
\hline PDLD & 13 & - & & & & & & & & \\
\hline HLD & 10 & - & & & & & & & & \\
\hline \multirow[t]{2}{*}{ HD } & 25 & 6 & $\begin{array}{r}9 \\
10 \\
11\end{array}$ & $\begin{array}{l}\mathbf{F} \\
\mathbf{F} \\
\mathbf{M}\end{array}$ & $\begin{array}{l}56 \\
50 \\
49\end{array}$ & $\begin{array}{l}\text { IV } \\
\text { IV } \\
\text { III }\end{array}$ & \multirow{2}{*}{$\begin{array}{l}\text { Pulmonary } \ddagger \\
\text { Pleural eff } \dagger \\
\text { Mediastinal } \\
\text { and hilar } \\
\text { Pulmonary } \\
\text { Pulmonary } \ddagger \\
\text { Pulmonary } \\
\text { pleural eff } \dagger\end{array}$} & $\begin{array}{l}\text { Relapse } \\
\text { Diagnosis } \\
\text { Diagnosis }\end{array}$ & $\begin{array}{l}\text { No } \\
\text { No } \\
\text { Partial }\end{array}$ & $\begin{array}{r}16 \S \\
2 \S \\
13 \S\end{array}$ \\
\hline & & & $\begin{array}{l}12 \\
13 \\
14\end{array}$ & $\begin{array}{l}\mathbf{F} \\
\mathbf{M} \\
\mathbf{M}\end{array}$ & $\begin{array}{l}63 \\
58 \\
62\end{array}$ & $\begin{array}{l}\text { III } \\
\text { IV } \\
\text { III }\end{array}$ & & $\begin{array}{l}\text { Diagnosis } \\
\text { Diagnosis } \\
\text { Relapse }\end{array}$ & $\begin{array}{l}\text { No } \\
\text { No } \\
\text { No }\end{array}$ & $\begin{array}{l}5 \S \\
3 \S \\
6 \S\end{array}$ \\
\hline \multirow[t]{2}{*}{ IL } & 2 & 2 & 15 & $\mathbf{M}$ & 58 & IV & \multirow{5}{*}{$\begin{array}{l}\text { Mediastinal } \\
\text { and hilar } \\
\text { Mediastinal } \\
\text { and hilar } \\
\text { Pulmonary } \\
\text { pleural eff }\end{array}$} & Diagnosis & No & $4 \S$ \\
\hline & & & 16 & $\mathbf{M}$ & 61 & IV & & Diagnosis & Complete & 18 \\
\hline $\mathbf{L L}$ & 1 & - & & & & & & & & \\
\hline UL & 1 & - & & & & & & & & \\
\hline Total & 86 & 16 & & & & & & & & \\
\hline
\end{tabular}

*PDLN = Poorly differentiated lymphocytic nodular; HLN=Histiocytic-lymphocytic nodular; WDLD=Well-differentiated lymphocytic diffuse; $P D L D=$ Poorly differentiated lymphocytic diffuse; HLD = Histiocytic-lymphocytic diffuse; HD=Histiocytic diffuse; IL =Immunoblastic lymphadenopathy; $L L=$ Lennert's lymphoma; $U L=$ Undifferentiated lymphoma.

†Toracentesis and positive cell cytology.

$\ddagger$ Necropsy confirmed intrathoracic lymphoma.

§Dead.

for 11 of these abnormalities, pulmonary lesions for eight, and pleural effusions for five. The lymphadenopathy was bilateral in four patients. The pulmonary lesions were all unilateral and were homogeneous in four patients, patchy "pneumonic" in three, and peribronchial in one. In all these patients a diagnosis of pulmonary infection, haemorrhage, infarction, or druginduced lung disease was considered unlikely from the clinical and laboratory evidence. In three intrathoracic lymphoma was confirmed at necropsy and in three others the lesions resolved partially or completely after cytotoxic therapy. Thoracentesis and cytological examination of the fluid were done in four of the five patients with $N$ pleural effusion. The pleural fluid was strawcoloured in two and "turbid" in two, with numerous lymphomatous cells present in all cases. In the fifth patient the effusion resolved completely after cytotoxic therapy.

The radiographic abnormalities were present at the time of initial diagnosis of NHL in 11 patients ? and in seven of these patients the intrathoracic lesions subsequently showed partial or complete resolution after treatment. The abnormalities were first seen at the time of relapse in five patients; only one subsequently responded partially to treatment. One patient who had mediastinal N 
and hilar lymphadenopathy at presentation that responded partially to treatment later developed pleural effusion at the time of relapse.

The lymphoma was at an advanced clinical stage (stage III or IV) at initial presentation in all 16 patients, and they were all treated with intermittent combination chemotherapy; two patients (cases 2 and 5) also received radiotherapy.

The figure shows the survival time of the patients after detection of the radiographic abnormalities, divided into non-responders (no resolution of intrathoracic disease after cytotoxic therapy) and responders (partial or complete resolution of intrathoracic disease). Seven of the eight nonresponders died within six months. Necropsy was performed on three patients (nos 6,9 , and 13), and this confirmed the presence of intrathoracic lymphoma. Among the responders only two have died. One patient (no 3) died from alcoholic liver disease, and there was no evidence of lymphoma at necropsy.

\section{Discussion}

In the present study $19 \%$ of patients with NHL had evidence of intrathoracic involvement; in two-thirds the lesions were evident at the time of

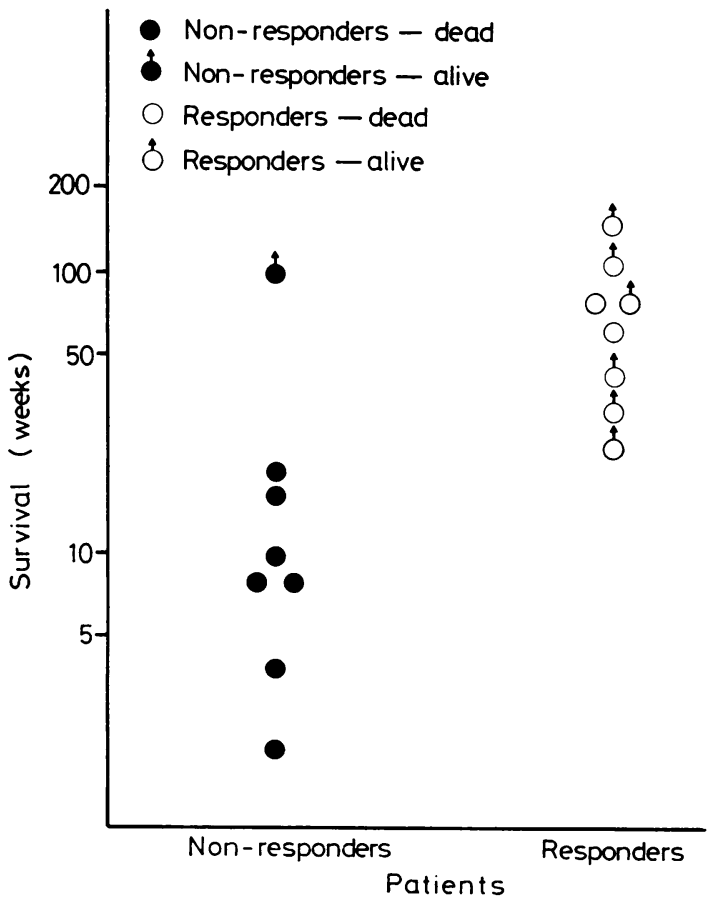

Survival time after detection of radiographic abnormalities. initial diagnosis and in the remainder at relapse. The lymphoma was at an advanced clinical stage in all patients with intrathoracic disease. Treatment was more successful in resolving intrathoracic lesions present at the time of initial diagnosis than in those that developed at relapse. Patients with non-responding lesions had a poor prognosis, most of them dying within six months.

Table 2 compares the intrathoracic manifestations of NHL in this series with previous reports (Rosenberg et al, 1961; Jones et al, 1973). Paratracheal, mediastinal, and hilar lymphadenopathy was the commonest manifestation in our study and was seen in nine patients - seven at initial presentation and two at relapse. Increased recognition of such involvement in the series reported by Jones et al (1973) has been attributed to the use of whole lung tomography as part of the diagnostic evaluation (Jones, 1974). In none of our patients was the mediastinal mass big enough to cause superior vena cava obstruction, a complication seen especially in diffuse lymphomas (Jones, 1974). One of our patients (no 5), however, developed stridor due to subacute tracheal obstruction while on remission induction therapy. The paratracheal lymphadenopathy causing the obstruction resolved after high dose corticosteroids, nitrogen mustard, and radiotherapy.

Pulmonary lesions were present in eight of our patients, four at the time of diagnosis and four at relapse. The diagnosis of such lesions in patients with lymphoma is difficult, and newer diagnostic techniques such as fibreoptic bronchoscopy, bronchial brushing, and needle biopsy may help to establish the precise nature of the lesions (Petty, 1975). Pleural effusion was seen in five patients-two at presentation and three at relapse. Thoracentesis and cytological examination established the lymphomatous nature of the effusion (Melamed, 1963) in four cases, and the other

Table 2 Prevalence of intrathoracic manifestations in non-Hodgkin's lymphoma

\begin{tabular}{|c|c|c|c|}
\hline & $\begin{array}{l}\text { Rosenberg* } \\
(1961)\end{array}$ & $\begin{array}{l}\text { Jones et al } \dagger \\
\text { (1973) }\end{array}$ & $\begin{array}{l}\text { Present } \\
\text { series } \ddagger\end{array}$ \\
\hline & $\%$ & $\%$ & $\%$ \\
\hline $\begin{array}{l}\text { Paratracheal mediastinal } \\
\text { and hilar lymphadenopathy }\end{array}$ & $3 \cdot 2$ & $\begin{array}{l}18 \text { (nodular) } \\
24 \text { (diffuse) }\end{array}$ & $10 \cdot 5$ \\
\hline $\begin{array}{l}\text { Pulmonary lesions } \\
\text { Pleural effusion }\end{array}$ & $\begin{array}{l}\text { NR } \\
\text { NR }\end{array}$ & $\begin{array}{l}\text { NR } \\
7 \text { (nodular) } \\
12 \text { (diffuse) }\end{array}$ & $\begin{array}{l}9 \cdot 3 \\
5 \cdot 8\end{array}$ \\
\hline
\end{tabular}

*Incidence in untreated patients.

†Untreated patients divided into nodular and diffuse lymphoma groups.

$\ddagger$ Overall incidence $18.6 \%$

$\mathrm{NR}=$ Not recorded. 
resolved completely after chemotherapy. Pleural effusion was associated with mediastinal lymphadenopathy in one patient, underlying pulmonary lesions in two, and both mediastinal and parenchymal disease in another. Similar associations have been noted by others (Jones et al, 1973; Weick et al, 1973). The fluid was straw-coloured in the two patients with nodular lymphoma, a setting where chylous effusion is known to be more common (Arthur, 1968).

Pleural effusion is usually a poor prognostic sign in lymphoma, especially if lymphomatous cells are present in the fluid (Weick et al, 1973). In the present series three patients with pleural effusion showed a complete response to chemotherapy and were alive six or more months later. Resolution of pulmonary lesions and paratracheal, mediastinal, and hilar lymphadenopathy after cytotoxic therapy was also associated with survival beyond six months. Seven of the eight non-responders in the whole series died within six months of detection of the radiographic abnormalities compared with the single fatality (at 13 months) among the eight patients in whom the intrathoracic lesions resolved after cytotoxic therapy. Accordingly, response of intrathoracic lesions to therapy would appear to indicate a better prognosis.

We thank Mrs M Nicol for preparing the figure and Mr W R Clifton for photographic help.

\section{References}

Arthur, K (1968). Follicular lymphoma-A review of 58 cases. Clinical Radiology, 19, 347-350.
Braylan, R C, Jaffe, E S, and Berard, C W (1975). Malignant lymphomas: current classification and new observations. Pathology Annual 1975, 10, 213270.

Carbone, P P, Kaplan, H S, Musshoff, K, Smithers, D W, and Tubiana, M (1971). Report of the committee on Hodgkin's disease staging classification. Cancer Research, 31, 1860-1861.

Jones, S E, Fuks, Z, Bull, M, Kadin, M E, Dorfman R F, Kaplan, H S, Rosenberg, S A, and Kim, H (1973). Non-Hodgkin's lymphomas IV. Clinicopathologic correlation in 405 cases. Cancer, 31, 806-823.

Jones, S E (1974). Clinical features and course of the non-Hodgkin's lymphomas. Clinics in Haematology, 3, 131-160.

Macdonald, J B (1977). Lung involvement in Hodgkin's disease. Thorax, 32, 664-667.

Melamed, M R (1963). The cytological presentation of malignant lymphomas and related diseases in effusions. Cancer, 16, 413-431.

Moran, E M, and Ultmann, J E (1974). Clinical features and course of Hodgkin's disease. Clinics in Haematology, 3, 91-129.

Petty, T L (editor) (1975). The contemporary approach to pulmonary diagnosis. In Pulmonary Diagnostic Techniques, pp 249-263. Lea and Febiger, Philadelphia.

Rosenberg, S A, Diamond, H D, Jazlowitz, B, and Craver, L F (1961). Lymphosarcoma: a review of 1269 cases. Medicine, 40, 31-84.

Weick, J K, Kiely, J M, Harrison, E G, Carr, D T, and Scanlon, P W (1973). Pleural effusion in lymphoma. Cancer, 31, 848-853.

Requests for reprints to: Professor M E Schonell, School of Medicine, The St George Hospital, Kogarah, NSW 2217. 